\title{
Fgf negative regulators control early chick somite myogenesis
}

\author{
Muhammad Abu-Elmagd ${ }^{1,2,3^{*}}$, Katarzyna Goljanek-Whysall ${ }^{4}$, Grant Wheeler ${ }^{2}$, Andrea Münsterberg ${ }^{2}$ \\ From 2nd International Genomic Medical Conference (IGMC 2013) \\ Jeddah, Kingdom of Saudi Arabia. 24-27 November 2013
}

\section{Background}

Negative regulators of the signalling transduction cascades have been shown to play critical role in controlling different aspects of normal embryonic development [1,2]. It is believed that these regulators control FGF signalling through a negative feedback mechanism [3]. The role of the FGF negative regulators during somite myogenesis is still not clear. In the current study, we tried to shed some light on FGF signalling through their negative regulators during early chick somite myogenesis.

\section{Materials and methods}

Chick embryos at $\mathrm{HH} 7-\mathrm{HH} 25$ were obtained by incubating white leghorn fertilised eggs at $38^{\circ} \mathrm{C}$ for the desired times. Single and double In situ hybridisation for the FGF negative regulators with other myogenic markers at different stages of chick embryos were carried out. Embryos were then sectioned and their expression pattern was critically analysed. For the functional analysis, epithelial somites were targeted for injection of different expression constructs. Embryos were then fixed and whole mount in situ hybridisation for MyoD and Mgn probes was carried out.

\section{Results}

Our results show that a number of FGF negative regulators are expressed in somites and their expression overlaps with that of MyoD and Mgn expression. Using gain- and loss-of-function approach, a number of the FGF negative regulators show that they can block FGF expression.

\section{Conclusions}

A number of FGF negative regulators are expressed during early chick somites formation. These regulators are able to

\footnotetext{
* Correspondence: mabuelmagd@kau.edu.sa

'Centre of Excellence in Genomic Medicine Research, King Abdulaziz

University, Jeddah, Kingdom of Saudi Arabia

Full list of author information is available at the end of the article
}

regulate FGF activation of somite myogenesis. Our study shed some light on FGF signalling and their negative regulators during early chick somite myogenesis.

The authors would like to thank KACST, Saudi Arabia for funding the research project (Project Code: 13-BIO789-03).

\section{Authors' details}

${ }^{1}$ Centre of Excellence in Genomic Medicine Research, King Abdulaziz University, Jeddah, Kingdom of Saudi Arabia. ${ }^{2}$ School of Biological Sciences, University of East Anglia, Norwich, UK. ${ }^{3}$ Zoology Department, Faculty of Sciences, Minia University, Minia, Egypt. ${ }^{4}$ Department of Musculoskeletal Biology, Institute of Ageing and Chronic Disease, Faculty of Health and Life Sciences, University of Liverpool, Liverpool, UK.

Published: 2 April 2014

\section{References}

1. Neumann CJ: Hedgehogs as negative regulators of the cell cycle. Cell Cycle 2005, 4(9):1139-40.

2. Thien $C B$, Langdon WY: Negative regulation of PTK signalling by $\mathrm{Cbl}$ proteins. Growth Factors 2005, 23(2):161-7.

3. Labalette C, Bouchoucha YX, Wassef MA, Gongal PA, Le Men J, Becker T, Gilardi-Hebenstreit $P$, Charnay $P$ : Hindbrain patterning requires fine-tuning of early krox20 transcription by Sprouty-4. Development 2011, 138(2):317-26.

doi:10.1186/1471-2164-15-S2-P18

Cite this article as: Abu-Elmagd et al:: Fgf negative regulators control early chick somite myogenesis. BMC Genomics 2014 15(Suppl 2):P18.

Submit your next manuscript to BioMed Central and take full advantage of:

- Convenient online submission

- Thorough peer review

- No space constraints or color figure charges

- Immediate publication on acceptance

- Inclusion in PubMed, CAS, Scopus and Google Scholar

- Research which is freely available for redistribution
C Biomed Central

(c) 2014 Abu-Elmagd et al; licensee BioMed Central Ltd. This is an Open Access article distributed under the terms of the Creative Commons Attribution License (http://creativecommons.org/licenses/by/2.0), which permits unrestricted use, distribution, and reproduction in any medium, provided the original work is properly cited. 